FILOLOGIJA 69, Zagreb 2017.

UDK 81'367.625.43:82-141(497.571)

https://dx.doi.org/10.21857/94kl4cxqlm Izvorni znanstveni članak Primljen 30.IV.2017.

Sandra Požar Prihvaćen za tisak 25.IX.2017.

Staroslavenski institut

Demetrova 11, HR-10000 Zagreb

sudec@stin.hr

\title{
STUPANJ POPRIDJEVLJENOSTI PARTICIPA I NJEGOV ODRAZ U LEKSIKOGRAFIJI: PRIMJER PASIVNIH PRETERITNIH PARTICIPA $S$ PREFIKSOM NE- IZ KORPUSA DRUGOGA BERAMSKOGA BREVIJARA
}

\begin{abstract}
Participi su po svojoj naravi dvojna kategorija, a njihovo je popridjevljenje teorijski problem u tvorbi riječi, ponajprije zbog podudarnosti sintaktičkih služba pridjeva i participa, koja upravo i omogućuje popridjevljenje. Između pravih, glagolskih participa i potpuno popridjevljenih pasivnih participa, tj. pridjeva, nalazi se najbrojnija skupina oblika koji se ne mogu tumačiti jednoznačno. Čitav taj raspon oblika od glagola do pridjeva bio je predmet ovoga istraživanja, čiji je cilj bio utvrditi na kojem su stupnju popridjevljenosti oblici s negacijskim prefiksom iz korpusa Drugoga beramskoga brevijara iz baze podataka Znanstvenoga centra izvrsnosti za hrvatsko glagoljaštvo koji su pri gramatičkom označavanju određeni ili kao pasivni participi preterita ili kao pridjevi, te proučiti kako se ova teorijski problematična pojava odražava na leksikografsku obradu, koja po svojoj naravi teži preciznosti i jednoznačnosti. ${ }^{1}$
\end{abstract}

\footnotetext{
${ }^{1}$ Članak se zasniva na izlaganju pod naslovom »Stupanj popridjevljenosti participa i njegov odraz u leksikografiji: na građi Rječnika crkvenoslavenskoga jezika hrvatske redakcije i rječnika Drugoga beramskog brevijara«. Za ovu je prigodu istraživanje usredotočeno na korpus Drugoga beramskoga brevijara i dopunjeno potvrdama iz drugoga dijela brevijara, koji je unesen u računalni program Beram tijekom 2016. godine. Prema potrebi se kao dopunski uključuje korpus Kartoteke Rječnika crkvenoslavenskoga jezika hrvatske redakcije (RCJHR). Istraživanje je provedeno u okviru projekta Znanstvenoga centra izvrsnosti za hrvatsko glagoljaštvo, koji novčano podupire Ministarstvo znanosti i obrazovanja Republike Hrvatske.
} 
Sandra Požar: Stupanj popridjevljenosti participa i njegov odraz u leksikografiji...

FILOLOGIJA 69(2017), 61-82

\section{Teorijske napomene}

Preobrazba ili konverzija tvorbeni je postupak kojim riječ mijenja kategorijalnu pripadnost bez izrazne promjene. S. Babić smatra taj postupak rubom tvorbe riječi jer se pri njemu ne upotrebljava nikakvo tvorbeno sredstvo (Babić 2002:50). To nije jedini način na koji se može pristupiti ovoj pojavi: neki ju autori ne smatraju zasebnim tvorbenim načinom, nego podvrstom izvođenja, nultom sufiksacijom (Bauer 2002:32). No u hrvatskoj jezikoslovnoj tradiciji takvo gledište nije uobičajeno jer je nulta sufiksacija naziv za postupak pri kojem se osnovi ništa ne dodaje nakon uklanjanja nastavka. Postupak preobrazbe tipičan je, prema tom pristupu, za jezike koji nemaju bogatu morfologiju, primjerice engleski, dok u slavenskim jezicima taj tvorbeni način nije čest jer imaju bogat sufiksalni inventar. ${ }^{2}$

Preobrazba participa u pridjeve, poznata kao popridjevljenje ili adjektivizacija, problematična je i iz drugih razloga. Dijakronijski gledano, izvor je problema u tome što su participni oblici povijesno fluidni, odnosno njihov se položaj kao vrste riječi mijenja u vremenu (Matthews 1991:56-57). Popridjevljenje participa odvijalo se $u$ dugom razdoblju i taj je tvorbeni način u starocrkvenoslavenskom jeziku naslijeđen. Zbog toga su različiti participi-pridjevi $u$ jednom vremenskom odsječku na različitim stupnjevima popridjevljenja. Tako su nekadašnje popridjevljenice sa sufiksima -ti -l- u potpunosti prepuštene etimologiji, starocrkvenoslavenski pridjevi lakomø i pitomø još se mogu dovesti u vezu s glagolima (bliskima onima od kojih su ti oblici izvedeni, a koji su se izgubili), ali su ipak pridjevi, dok su mnogi hrvatskocrkvenoslavenski oblici između dviju kategorija, odnosno u objema. Stoga se može reći da je popridjevljenje, kada se promatra sinkronijski, stupnjevita pojava. Osim toga stupnjevitost vrijedi i za sva$\mathrm{ku}$ pojedinu potvrdu jer se značenja mogu razlikovati ovisno o kontekstu.

Pri dijakronijskom promatranju treba se osvrnuti i na leksikalizaciju. Pri leksikalizaciji riječ se prestaje osjećati tvorbenom, što bi u slučaju popridjevljenja participa značilo da se oni prestaju osjećati izravno povezanima s glagolom. Kod tipičnih tvorbenih načina leksikalizacija podrazumijeva prekid tvorbene veze, koji može uzrokovati gubljenje glasovnoga ili značenjskoga odnosa među osnovnom riječi i tvorenicom. U slučaju popridjevljenja participa u središtu je zanimanja, dakako, značenjska promjena. U kontekstu leksikalizacije važna je i čestoća, odnosno - budući da je riječ o pisanom jeziku - broj potvrda pojedinoga oblika; stoga je ko-

$2 \mathrm{~S}$ druge strane, $\mathrm{u}$ nekim se pristupima upravo zato zagovara (usp. Gaeta 2013:147). 
Sandra Požar: Stupanj popridjevljenosti participa i njegov odraz u leksikografiji... FILOLOGIJA 69(2017), 61-82

risno utvrditi one koji imaju više potvrda. Iako bi to bilo opravdanije odnosno pouzdanije kod većega korpusa, npr. onoga Kartoteke RCJHR, i ovdje je ilustrativno, a treba dodati da i odgovara odnosima u korpusu Kartoteke RCJHR.

Leksikalizacija zahvaća tvorbene postupke postupno. Kod tipičnih tvorbenih načina, poput izvođenja, veći broj potvrda nekoga tvorbenoga uzorka upućuje na njegov viši stupanj leksikaliziranosti, dok tzv. ad hoc ili prigodne tvorenice ${ }^{3}$ upućuju na plodnost tvorbenoga uzorka (usp. Bauer 2003:86-87). Ako bi se na taj način promatrala preobrazba, iako nije tipičan tvorbeni način u hrvatskom crkvenoslavenskom jeziku, moglo bi se također utvrditi da više potvrda pojedinoga oblika (koje upućuju na njegovu manje ili više svjesnu upotrebu) znači njegovu leksikaliziranost, odnosno prihvaćenost ili institucionaliziranost (usp. Bauer 2003:86-87) u zajednici korisnika jezika, a samim time zahtijeva uključivanje u rječničku obradu. To se može oprimjeriti parom neobrêzans i neokroens 'neobrezan', u kojem je prvi oblik dobro poznat i prihvaćen među govornicima, tj. korisnicima, dotle da se rabi čak i pri elipsi imenice (kvazisupstantivizirano), npr. da ne v'zveselet' se deĉeri filisteiskie ni vzradû̂t' se deĉeri neobrezanihb (I 209c) ${ }^{4}$, dok je drugi u korpusu upotrijebljen samo jedanput (da priišal' bi skvozê te neokroenb i nečists (I 28a); lat. incircumcisus et immundus; Izaija $52,1)$ i nije razumljiv izvan konteksta jer nije institucionaliziran. Dodatna provjera položaja dotičnih oblika u dopunskom korpusu Kartoteke RCJ$H R$ pokazuje podudarno stanje: oblik neobrêzanı označen je kao pridjev, dok je oblik neokroeno u korpusu Kartoteke RCJHR jedina participna potvrda inače dobro potvrđena glagola okroiti pod koji je uvršten. ${ }^{5}$

Kada se popridjevljenje participa promatra sinkronijski, glavni je problem pri njegovu definiranju to što se preobrazba kao tvorbeni način obično definira promjenom sintaktičke službe. Međutim, sintaktičke su službe pasivnih participa, koji se u ovom radu promatraju, podudarne pridjevskima: atribut, dio (imenskoga) predikata ${ }^{6}$ i sekundarni predikat, kojima se mogu dodati subjektna i objektna služba u slučajevima elipse imenice ili pravoga poimeničenja (usp. Večerka 1993:102-103).

${ }^{3}$ I. Marković za engleski pojam nonce word rabi naziv okazionalizam ili prigodnica (Marković 2012:131).

${ }^{4}$ Pri navođenju potvrda rimskim je brojkama naveden dio brevijara (I. - temporal; II. - sanktoral), a u nastavku paginacija (broj lista i oznaka stupca).

${ }^{5}$ Pojavljuje se samo u $\operatorname{BrVO}(39 a)$.

${ }^{6}$ Ako je participni oblik posve glagolski, posrijedi je dakako, glagolski, a ne imenski predikat. 
Sandra Požar: Stupanj popridjevljenosti participa i njegov odraz u leksikografiji...

FILOLOGIJA 69(2017), 61-82

Kada se kao kriterij zbog podudarnosti isključe oblik i sintaktička služba, za razmatranje ostaje značenje. Tradicionalno se popridjevljenje definira na temelju stalnoga svojstva, nasuprot privremenomu svojstvu koje postoji za trajanja radnje izražene glagolom. Kada particip prestane obilježavati vrijeme za koje se neka radnja ili stanje pripisuje predmetu i kada umjesto privremenoga svojstva počinje značiti stalno, tada prelazi u pridjev (Belić 1958:244; 247). Ti se pojmovi mogu povezati s pojmovima događajnosti i stativnosti u suvremenim jezikoslovnim pristupima (usp. Levin-Rappaport 1986:625, bilj. 3).

Problem je, međutim, katkad definirati stalno svojstvo. Zbog toga je $\mathrm{u}$ opisu popridjevljenja participa $\mathrm{u}$ hrvatskom crkvenoslavenskom $\mathrm{S}$. Sudec nastojala utvrditi posredne pokazatelje popridjevljenosti (Sudec 2010:202-210). Na prvom je mjestu stupnjevanje, koje pretpostavlja stalno svojstvo, a predstavlja i formalni odraz popridjevljenja. ${ }^{7}$ Međutim, treba napomenuti da je ta činjenica podložna raspravi jer su potvrđeni apsolutni komparativi, pa nema pravoga stupnjevanja, usp. sljedeće primjere pasivnih participa preterita: svršenêiša BrVO (latinski oblik perfectorum nije u komparativu, tako da je $\mathrm{u}$ hrvatskom crkvenoslavenskom obliku riječ o apsolutnom komparativu), učenêiše BrVO (apsolutni komparativ s elativnom službom, prema latinskom doctissimis; uobičajeno u hrvatskom crkvenoslavenskom, usp. Požar 2014:163-164). Primjer je komparativne morfologije i prefiksacija elativnim prefiksom prê- i pri-, npr. prêvzapuĉen (lat. densissimus), prêskušens (lat. probatissimus), prêslavlens (lat. praepotens), prêukrašeno (lat. pretiosissimus); prinaučeno (lat. eruditissimus). ${ }^{8}$

Kako mnogi pridjevi nemaju značenjski preduvjet da budu stupnjevani, kao sigurniji pokazatelj u Sudec (2010:isto) utvrđena je značenjska promjena, a osnovni je način modalizacija, i to pojava modalnoga potencijalnoga značenja pasivnih participa (usp. Đorđić 1931:134-135; Sudec 2010:205, Požar 2014:156). Tu je pojavu u starocrkvenoslavenskom potaknuo grčki glagolski pridjev I., koji je imao i pasivno i modalno potencijalno značenje (Dukat 1990:193). Zbog dvojnoga značenja starocrkvenoslavenski su pridjevi i pasivni participi kojima su se prevodili grčki glagolski pridjevi I. semantičkim kalkiranjem dobili i modalno značenje. Iz starocrkvenoslavenskoga ta je pojava prenesena u hrvatski crkvenoslavenski, gdje je uspostavljen daljnji razvoj u odnosu prema latinskim pridjevima izvedenim sufiksom -bilis (Sudec 2010:204). Od pasivnih preteritnih participa na taj su način nastali ovi pridjevi: vêrovans 'pouzdan, vjerodo-

\footnotetext{
${ }^{7}$ Usp. slično za starocrkvenoslavenski u Đorđić 1931:135, bilj. 1.

8 Treba skrenuti pozornost na to da su i neke od latinskih usporednica participi, pa je i tu riječ o preslikavanju.
} 
Sandra Požar: Stupanj popridjevljenosti participa i njegov odraz u leksikografiji... FILOLOGIJA 69(2017), 61-82

stojan', nevêrovanb 'nevjerojatan' (incredibilis), neizglagolans 'neopisiv' (inenarrabilis), nemučens 'nesposoban za patnju' (impassibilis), nenasiĉens 'nezasitan' (insatiabilis), nepomišlenv 'nezamisliv' (incogitabilis), nepripodoblens 'neusporediv' (incomparabilis). Stalno svojstvo moglo se pretpostaviti tek za pojedine oblike kao što su blagoslovlenv, blaženı 'blažen, sretan, blagoslovljen; svet' i vzlûblens 'ljubljen, drag' (Sudec 2010:210). ${ }^{9}$

Kada se utvrde i iz razmatranja izostave pravi pridjevi, ostaje niz participnih oblika koji imaju i glagolske i pridjevske značajke. Jezikoslovna literatura o problemu glagolskih i pridjevnih pasivnih participa i o kriterijima njihova razlikovanja bogata je i široka, a bavi se uglavnom stanjem u engleskom jeziku. Sažet pregled kriterija iz prijašnjih radova u hrvatskom jezikoslovlju nude B. Knežević i I. Brdar (Knežević-Brdar 2010:210-215). Ovdje se može izdvojiti ono što je zanimljivo za oblike iz korpusa: prošli participi s niječnim prefiksom pridjevni su; prošli participi kao dopuna glagolima činiti se, ostati, zvučati i izgledati pridjevni su; samo pridjevi mogu služiti kao prenominalni modifikatori. ${ }^{10}$ Ti se kriteriji mogu primijeniti i na crkvenoslavensku građu, te su, iako ne na formalan način, prepoznati već u opisu starocrkvenoslavenskih trpnih participa P. Đorđića (Đorđić 1931).

P. Sleeman na tragu formalnih postavaka D. Embicka (2004) uspostavila je za germanske, a potom i za romanske jezike ljestvicu popridjevljenosti pasivnih participa koja ima četiri značenjska stupnja: događajni (engl. eventive) odnosno glagolski oblici; oblici koji se mogu tumačiti događajno, odnosno imaju događajno obilježje; rezultativni oblici; stativni, tj. pridjevni oblici (Sleeman 2011; Sleeman 2014; Sleeman - Niculescu 2015). U hrvatskom crkvenoslavenskom jeziku mogu se utvrditi tri glavna stupnja od navedenih četiriju, bez rezultativnosti, jer u slavenskim jezicima nije tipično da se ona izražava participom koji je sekundarni predikat. Dio potvrda u službi sekundarnoga predikata, doduše, ima značenje rezultativnosti, ali ne u strogom smislu u kojem se inače definira (kao rezultat radnje finitnoga glagola), ${ }^{11}$ nego shvaćene $u$ širem smislu: stanje ili svojstvo kao rezultat događaja. ${ }^{12}$ Slično tomu, $u$ korpusu su potvrđeni i oblici u predi-

\footnotetext{
9 Potonji je, doduše, u RCJHR označen kao popridjevljeni particip, »adj. ptc.« (RCJHR 2000:402).

${ }^{10}$ Za ovdje istraživani jezik može se ta tvrdnja preoblikovati i reći umjesto prenominalni: atributni modifikatori. Mogućnost modifikacije imenice jedna je od glavnih značajka kojima se opisuju pridjevi, čak i u najstrožim formalnim pristupima (usp. Baker 2003:192).

${ }^{11}$ Usp. primjerice u Marković 2009.

12 Na hrvatski je jezik to tumačenje primijenjeno u Knežević-Brdar (2010), po uzoru na kognitivistički pristup u Belaj 2002.
} 
Sandra Požar: Stupanj popridjevljenosti participa i njegov odraz u leksikografiji...

FILOLOGIJA 69(2017), 61-82

katnoj službi koji imaju rezultativno značenje u širem smislu: riječ je o dopunama polusponskomu glagolu prêbiti u značenju 'ostati'.

\section{Metodološke napomene}

Kao korpus ovoga istraživanja odabrana je skupina oblika s prefiksom ne- iz Drugoga beramskoga (ili ljubljanskoga) brevijara koji su pri gramatičkom označavanju teksta u digitalnoj bazi Beram označeni bilo kao participi ili kao pridjevi. ${ }^{13}$ Zanijekani oblici odabrani su iz triju praktičnih razloga. Prvo, prefigirani su oblici dohvatljivi za prikupljanje i pregled na temelju azbučnoga popisa, upravo zahvaljujući prefiksu i tomu što su u oblikovanju radne inačice rječnika Drugoga beramskoga brevijara određeni kao natuknice, dakle pretpostavljeno je da su u nekoj mjeri popridjevljeni. Drugo, na taj je način lako odabran mali uzorak za istraživanje. ${ }^{14}$ Treći je razlog to što su pri gramatičkom označavanju pojavnica u programu Beram takvi oblici izazivali nedoumice sudionika projekta o tome $\mathrm{u}$ koju ih kategoriju riječi svrstati i treba li u natuknicu uključiti negacijsku česticu. ${ }^{15}$

Prefigiranost niječnim prefiksom jedan je od kriterija koji se još od sedamdesetih godina 20. stoljeća navode u literaturi kao pokazatelji pridjevnosti participa (T. Wasow; usp. Levin-Rappaport 1986:625-626). Očekuje se da se time automatski isključe glagolski participi. No u korpusu se u vezi s tim pojavljuje iznimka. ${ }^{16}$

U odabir korpusa uvedena su nadalje još dva ograničenja. Prvo je ograničenje na pasivne participe jer su oni kao takvi problematični zbog sklonidbene podudarnosti s pridjevima. Drugo: $u$ obzir su uzeti samo preteritni pasivni participi. Naime, kod prezentskih pasivnih participa lako je utvrditi značenjsku promjenu (najčešće imaju značenje pasivne mogućnosti; usp. Sudec 2010:208), što ih nedvojbeno čini pravim pridjevima. Usporedno s tim preteritni particip više ne upućuje na prošlu ili prethodnu radnju, pa postaje samo glagolski pridjev (usp. Đorđić 1930; Haspelmath 1994:162). Nadalje, "preteritni“ je particip pogodan za istraživanje jer je -

13 Ne treba posebno naglašavati da u obzir nisu uzeti participi glagola kojima je negacijska čestica dio osnove, kao primjerice nebrêci, nedostati, nenavidêti, ali je zanimljivo spomenuti da je takva tvorbena mogućnost postojala u jezičnoj prošlosti.

14 U početku je istraživanje, kako je već spomenuto, bilo provođeno na korpusu iz Kartoteke RCJHR, koja u azbučnom katalogu sadrži više od 376.000 kartica.

${ }^{15}$ Doduše, više je nedoumica bilo kod aktivnih participa. No i kod pasivnih participa, koji se ovdje istražuju, pokazuje se da u nekim slučajevima negacijski prefiks treba odvojiti od participa kao česticu.

${ }^{16} \mathrm{O}$ njoj je riječ u odjeljku 3.1.1. 
Sandra Požar: Stupanj popridjevljenosti participa i njegov odraz u leksikografiji... FILOLOGIJA 69(2017), 61-82

s obzirom na to da je u velikoj mjeri istisnuo prezentski pasivni particip bogato potvrđen.

Da bi se utvrdilo je li neki participni oblik popridjevljen, provjereni su niže navedeni sintaktički i značenjski čimbenici, a zbog morfološke i sintaktičke podudarnosti pridjeva i pasivnih participa važnijima su se pokazali oni značenjski.

a) sintaktički čimbenici: jesu li oblici s više potvrda potvrđeni u svim službama; jesu li oblici upotrijebljeni i eliptično umjesto imenice; jesu li participi potvrđeni u dugom obliku; imaju li participi dopune i kakve su one po naravi; može li se negacijska čestica odvojiti od participnoga oblika;

b) značenjski čimbenici: ima li značenjskoga pomaka ili promjene; je li značenje uvjetovano kontekstom ili je jasno i kada je oblik samostalan; ${ }^{17}$ kakav je glagolski vid finitnoga glagola; ako je nesvršen, može li ipak biti riječ o privremenu, kontekstom uvjetovanu svojstvu; koje je vrijeme odvijanja glagolske radnje; koji je vremenski odnos participne radnje prema radnji glavnoga glagola; jesu li participni oblici izvedeni isključivo od osnova svršenih glagola.

\section{Raščlamba}

\subsection{Posebnosti sintaktičkih služba}

\subsubsection{Dio (imenskoga) predikata}

Ključna je činjenica za razlikovanje glagolskoga i imenskoga predikata čiji su dio ovdje istraživani oblici mogućnost odvajanja negacijske čestice bez posljedica za smislenost. Riječ je zapravo o razlikovanju rečenične i sastavničke negacije. ${ }^{18}$ To se pak može provjeriti mogućnošću preoblike u drugi tip pasivne konstrukcije (npr. se-pasiv). Takvom je provjerom za neke od potvrda utvrđeno da negacijski prefiks treba odvojiti od participa kao česticu, npr. êko aĉe *neobraĉenb budets kto i sbvrš(e)nv kako mlad(ê)n(a)cb ne možeto duše svoee dati za h(rbst)a (I 43d). Negacija je naime u toj potvrdi rečenična i odnosi se i na oblik sbvrš(e)nv: »ako tkogod ne bude obraćen i

17 To je kriterij za institucionaliziranost leksema u Brinton - Closs Traugott 2005:45. Međutim, treba napomenuti da razumijevanje izvan konteksta ovisi o tome je li značenje osnovnoga glagola uopćeno ili konkretno (usp. Silić-Pranjković 2005:301). Primjerice, oblik netežanı vrlo je lako razumljiv i izvan sintagme niva netežana jer se glagol težati uglavnom odnosi na obrađivanje zemlje.

18 Usp. više o tome u monografskom opisu negacije u hrvatskom crkvenoslavenskom jeziku A. Kovačević (Kovačević 2016:137 i dalje). 
Sandra Požar: Stupanj popridjevljenosti participa i njegov odraz u leksikografiji... FILOLOGIJA 69(2017), 61-82

savršen kao dijete «. ${ }^{19}$ Drugi je takav slučaj ova potvrda: da d(ê)vi čas'nimb roždeniemb isbšad'še blud'stva glasomb *neoskvrneni bile bi (I 3d). Osim takvih slučajeva ima i onih kod kojih nije jednostavno odrediti je li negacija morfološka ili sintaktička jer su dvosmisleni, kao što je ustvrdila A. Kovačević u navedenu djelu (Kovačević 2016:141). Potvrda na eg'da ničtože nevrežden' bisto sudiê povêle da glavu ego mečems usek'nuts (II 48d, služba sv. Bonifaciju) dvojbena je zbog problematična niječnoga slaganja (usp. Kovačević 2016:225 i dalje). Ako niječno slaganje nije provedeno, onda je negacijski prefiks suvišan, a ako jest, onda negacijsku česticu treba odvojiti od participa. ${ }^{20}$

Kada su navedeni dvojbeni slučajevi isključeni, za dvije se potvrde mogla utvrditi posebnost da morfologiziraju sintaktičku (rečeničnu) negaciju. Prva je od njih ova: êk(o) neostavlenb e(stb) va ade ni plto ego vide istleniê (I 169a). Da je riječ o rečeničnoj negaciji, pokazuje niječna inačica sastavnoga veznika $n i$ koja očituje usporednost sintaktičke strukture rečenice. $S$ druge strane, argument da nije riječ o odvojenoj negacijskoj čestici (ne ostavlenb) jest red riječi; naime $\mathrm{u}$ tom slučaju bi se negacijska čestica (tj. prefiks) vezala uz finitni glagol (kopulu): *nêsto ostavlens (usp. Kovačević 2016:137-138). Drugi je takav slučaj ovaj: otêtb e(stb) ĉits krep'čeiši saulovb leki da bi nepomazanb oliems (I 207d; Druga knjiga o Samuelu 1,21; lat. quasi non esset unctus oleo). Argument je i tu red riječi; usp. isto mjesto u BrVO (317a): êko ne bêše pomazan' olêem'.

Budući da je riječ o glagolskom predikatu, a time i o pravom, glagolskom participu, navedene potvrde strogo uzevši ne bi zahtijevale zasebnu leksikografsku obradu. Ipak, s obzirom na to da je pojava morfološkoga izražavanja sintaktičke negacije tvorbena činjenica, ne bi trebala izmaknuti leksikografskoj pažnji. Slično se može tvrditi i za atributnu potvrdu i vidê on'dê č(lovê)ka neodêvena rizami brač'nimi (I 226c, Mt 22,11, lat. et vidit ibi hominem non vestitutum vesti nuptiali), gdje oblik neodêvena sažima relativnu rečenicu, što je inače svojstvenije aktivnim participima.

Imenski predikat, uopće njegovo postojanje u ovakvim potvrdama može se utvrditi ako je particip popridjevljen. To se može tvrditi za većinu takvih potvrda jer je mahom riječ o dobro potvrđenim oblicima u fiksiranu značenju koje se najčešće odnosi na Bogorodicu ili koju drugu sveti$\mathrm{cu}$, iako se ti oblici još uvijek mogu preoblikovati u pasivnu konstrukciju, usp. npr. egože egda vzlûblû čista es(a)mo i egože kos'nu i nevreždena esamb (II

\footnotetext{
${ }^{19}$ Osim toga, postoji i složeni isključni veznik aĉe ne, koji se doduše uobičajeno pojavljuje s kondicionalom (usp. RCJHR 2000:103).

${ }^{20}$ Usp. i latinski: Sed cum nihil lesus esset. Da nije riječ o pogrešci u ovom rukopisu, potvrđuje isto stanje $\mathrm{u} \mathrm{BrN}_{2}$ (421a): no egda ničtože nevrêždenu b(i)si.
} 
Sandra Požar: Stupanj popridjevljenosti participa i njegov odraz u leksikografiji... FILOLOGIJA 69(2017), 61-82

12d; lat. Quem cum amavero, casta sum; cum tetigero, munda sum): neozlijeđena sam $\rightarrow$ nisam ozlijeđena $\rightarrow$ ne ozlijedim se.

Dio potvrda u službi imenskoga predikata služi kao dopuna polusponskomu glagolu prêbiti 'poživjeti, proboraviti' itd., koji u korpusu znači 'ostati' jer odgovara latinskim glagolima maneo, manere, mansi, mansus i permaneo, permanere, permansi, permansus; npr. tako i $d(\hat{e}) v a$ m(a)riê rodi g(ospod)a na nevrêždena prebi (I 25b). Teorijski se takvi oblici mogu smatrati i sekundarnim predikatom.

\subsubsection{Sekundarni predikat}

U skladu s funkcijom sekundarnoga predikata, koji dopunjuje subjekt ili objekt, u toj se službi oblici pojavljuju u nominativu i u akuzativu, npr. i neožžženb ot sasuda izide (I 36b); i dev'stvo moe nekos'neno i celo shraniši (II 166c). U drugom slučaju sudjeluju u prevođenju latinske konstrukcije dvostrukoga akuzativa (usp. Gortan-Gorski-Pauš 1966:191-193). Izvorno, u starocrkvenoslavenskom jeziku, takvi su oblici služili za prijevod grčkoga predikatnoga participa uz glagole opažanja u slučajevima kada se radnja izražena participom proteže na objekt (usp. Dukat 1990:323-325). Takva je ova potvrda iz korpusa: êko iûdu tolikimi služeĉa nepotvr'ždena počtovana vidis'mo i (II 109d-110a).

\subsubsection{Atribut}

Ono što razlikuje participne oblike $u$ atributnoj službi od oblika u službi (dijela) predikata i sekundarnoga predikata jest, kao i kod pridjeva, dugi oblik. On podrazumijeva da ti oblici mogu sudjelovati u izražavanju kategorije određenosti. U dugom je obliku gotovo polovina atributnih potvrda (17 od 31). Većina su članovi sintagme kojom se označava poznat pojam, pa se može govoriti o izražavanju kategorije određenosti tim oblicima (usp. Požar 2014:178-179), npr. iže bo duhom' s(ve)timo ot nekosnenie matere črêva cr(ê)kvê ob'novi se (I 48b), hvala budi o(t)cu nerojenomu (II 111b). Potvrde s instrumentalnim nastavkom pridjevske sklonidbe: $i$ radosto materinu imuĉi sa dêv'stvoms nevrêždenimb (I 33a); neotvorenimb črevoms d(ê) vi izide (I 166c) ne moraju se smatrati izrazom kategorije određenosti jer je to jedan od padeža u kojima mogu prevladati oblici pridjevske sklonidbe čak i kod onih pridjeva koji tu sklonidbu izvorno nisu imali (Sudec 2012:65-66).

\subsection{Pregled oblika i potvrda prema stupnjevima}

Od ukupno 71 potvrde 47 ih pripada višekratno potvrđenim oblicima (11 natuknica), a 24 jednokratnima, tako da je dobiveno 35 potencijalnih 
Sandra Požar: Stupanj popridjevljenosti participa i njegov odraz u leksikografiji...

FILOLOGIJA 69(2017), 61-82

natuknica. ${ }^{21}$ Participnih oblika koji imaju više od jedne potvrde u korpusu je ukupno jedanaest. Većina ih se pojavljuje u sve tri sintaktičke službe, a s obzirom na popridjevljenost mogu se podijeliti u dva stupnja: visoki, kojemu pripadaju pravi pridjevi, i srednji, koji obuhvaća popridjevljene participe.

Oblici s jednom potvrdom mogu se pojaviti u svakoj od triju služba i ima ih ukupno 24. Svojstvena su im sva tri glavna stupnja, što znači da osim pravih pridjeva i popridjevljenih participa ima i pravih, glagolskih participa koji sudjeluju u izricanju pasivnih konstrukcija. Oblici srednjega stupnja, popridjevljeni participi, većinom su u službi sekundarnoga predikata.

U pregledu koji slijedi uz natuknicu (ili potencijalnu natuknicu) navodi se značenje ako je riječ o pridjevu ili o manje jasnu značenju participa. Ako je oblik potvrđen u više sintaktičkih služba, potvrde se navode po službama ovim redom: predikat, sekundarni predikat, atribut. Po potrebi (kod problematičnih slučajeva) navodi se biblijsko mjesto i usporedni latinski tekst.

\subsubsection{Prvi stupanj: glagolski oblici}

Tomu stupnju pripadaju glagolski participi kojima se izražava pasiv, dakle riječ je o stupnju na kontinuumu između glagola i pridjeva, ali ne o stupnju popridjevljenosti. To su potvrde morfološki izražene sintaktičke negacije navedene naprijed (neostavlen $\mathrm{i}$ nepomazanb) te pogrešno označeni oblici kod kojih treba odvojiti niječnu česticu ( ${ }^{*}$ neobraĉen $\mathrm{i}{ }^{*}$ neoskvrbneno). Kako je već spomenuto, prve ne bi trebalo zasebno leksikografski obrađivati jer su glagolski oblici, ali zbog specifične tvorbe to zaslužuju.

neostavlenb: êk(o) neostavlenb e(stb) va ade ni pltb ego vide istleniê (I 169a); nepomazanb: otvržens e(stb) cits krepki saulovs k(a)ko da bi nepomazanb oliems (I 209c); otêtı e(stb) ĉito krep'čeiši saulovb leki da bi nepomazanb oliemb (I 207d). ${ }^{22}$

3.2.2. Drugi stupanj: popridjevljeni participi

Drugi ili srednji stupanj obuhvaća popridjevljene participe, koji su u rječničkoj obradi za RCJHR označeni kao »adj. ptc.« (usp. RCJHR 2000:XIII), što je dobrodošao iskorak u odnosu na postupak u Slovníku jazyka staroslověnského, koji inače služi kao uzor RCJHR-u, a u kojem takvi oblici nose gramatičku oznaku pridjeva. Značenje je tih oblika privremeno svojstvo koje se razaznaje iz konteksta, a u rečenici većinom služe kao se-

\footnotetext{
${ }^{21}$ Izraz natuknica rabi se, dakako, vrlo uvjetno.

22 Oblik nepomazans potvrđen je (tehnički) dvaput, ali u obje je potvrde riječ o istom biblijskom mjestu koje je $u$ antifoni parafrazirano u odnosu na brevijarsku lekciju.
} 
Sandra Požar: Stupanj popridjevljenosti participa i njegov odraz u leksikografiji... FILOLOGIJA 69(2017), 61-82

kundarni predikati. S obzirom na razlike u sintaktičkoj službi i značenjske nijanse, ovdje se može naznačiti postojanje podstupnjeva, među kojima je najzastupljeniji onaj koji obuhvaća sekundarne predikate. Preciznije razlikovanje podstupnjeva moglo bi se uspostaviti na temelju istraživanja većega korpusa nezanijekanih popridjevljenih participa.

U srednji stupanj među bolje potvrđenim oblicima iz korpusa ulaze potvrde oblika nevrêžden i nekosnen na nj odnose neizravno.

nevrêždent ${ }_{2}$

na eg'da ničtože nevrežden' bists sudiê povêle da glavu ego mečemb usek'nutb

(II 48d); poêhu b(og)u i izidoše veseleĉe se nevreždeni (II 66c); da otroci tvoi g(ospod)i iz'bavili se biše nevreždeni (I 118a); i znaemb zaĉititela suĉa g(ospod)a va vrême skr'bi trims mužems onims iže hoždahu va ogni nevrêždeni (II 87d); i radosto materinu imuci sa dêv'stvomb nevrêž'denimb (I 33a); ${ }^{23}$

nekosnens ${ }_{2}$

b(la)ž(e)nab(ogo)r(odi)ca m(a)riê eeže črêva nekosnena prebiše (I 29d); zdrava milosti plna g(ospod)b s toboû zbožbni pupak' čis'totôu iže ob'êtb nekos'nen' ženitvô̂u (II 32b); doms čistihb prsb (...) nekosnenb nê znâ̂ci muža sl(o)vomb poče s(i)na (I 53a); i dev'stvo moe nekos'neno $i$ celo shraniši (II 166c). ${ }^{24}$

U njima nije nužno riječ o potpunoj popridjevljenosti. Pridružuju im se potvrde koje imaju druge referente:

ideže prebi .d. dni nekos'nena (II 91a); b(o)ž(a)stvênô̂ pomoĉîu zaĉiĉaemb nekos'nenb izide (I 42d); s vêlikim' čudesemb nekosnenb êvi se (II 56d57a); vsa êže bêhu o(t)ca tvoego umrv'ša prežde .z. leto nekos'nena hranihs (II 5b); iže roĵ(e)n' ot čreva moego mater' me čistu ostavi i nekos'nenu (II 32a). ${ }^{25}$

U korpusu su jednom potvrdom posvjedočeni ovi oblici popridjevljenih participa:

neoprošen s 'neupitan': $i$ vedeno bistb romanb predb c(êsa)r(a) i nevproš(e)nb nače sv(ê)tl(i)mb gl(a)s(o)mb vap(i)ti reki h(rbst)bêninb es(a)mb (II 104b);

nezvanb: vidis'te ô̂e i ženu v gradê glasitu zalago že glasa êže biše greš'nica

\footnotetext{
${ }^{23}$ Iako je posrijedi atribut, svojstvo o kojem je riječ ipak je privremeno jer se kazuje (samo) to da je Bogorodica postala majkom ostavši djevica (usp. i napomenu o instrumentalu u odjeljku 3.1.3.).

24 Jedina potvrda ovoga oblika u kojoj nije prošlo glagolsko vrijeme.

25 Iako se ova potvrda odnosi na Bogorodicu, slično kao kod gornjega slučaja dêv'stvomb nevrêž'denimb, svojstvo se može tumačiti kao privremeno: nakon poroda je ostala čista i netaknuta, a iz izvanjezične je stvarnosti poznato da je to ostala trajno.
} 
Sandra Požar: Stupanj popridjevljenosti participa i njegov odraz u leksikografiji...

FILOLOGIJA 69(2017), 61-82

nezvana všad'ši na obeds ideže lazar' ee vzležaše vzis'kati milostivago zdraviê (II 89b-c);

neispovêdanb: pristupi ubo nes'povidana da vratila se bi obet'na (II 89d); ${ }^{26}$ nemučenь: sego egože vêruemb v svoem' božastvê nemučena na vêruemb ego $v^{\prime}$ našei pl'ti semr'tnoi mučena suĉa (I 65b);

neožežens: i neožžženb ot sasuda izide (I 36b);

neosêčenb 'neodsječen': drugo eže vidê eže ot gori neosečenb rukama udrže se kameno (I 257d; Danijel 2,45); lat. quod de monte abscissus est lapis sine manibus; ${ }^{27}$

nepotvrbždeno 'odbačen': êko iûdu tolikimi služeĉa nepotvr'ždena počtovana vidis'mo i (II 109d-110a); ${ }^{28}$

neprošenv 'nepozvan': na obêd' v'nide neprošena (I 136a), lat. non jussa;

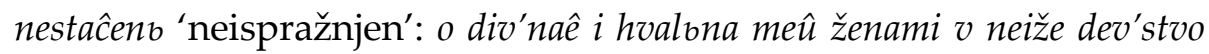

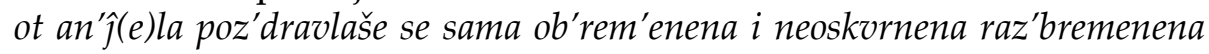
i nestaĉena êk(o) siko e(stb) ot an'ĵ(e)la pozdravlena zdrava milosti plna (II $32 a-32 b){ }^{29}$

U skupini ovoga stupnja ima i potvrda u atributnoj službi. Neke od njih članovi su sintagme koje imaju okolnosno, dakle priložno značenje, koje doduše može biti jasno izvan konteksta, ${ }^{30}$ ali je privremeno. To ih čini sličnima oblicima u sekundarnom predikatu koji tipično imaju značenje privremenoga svojstva. Stoga se mogu pridružiti njihovu polustupnju.

neotvorenb: neotvorenimb črevoms d(ê)vi izide (I 166c);

nepokaên 'nepokajan': po žestočastvîu tvoemu o č(lovê)če i nepokaênomu sr(bd)cu tvoemu s'biraeši sebi gnêvb (I 71d-72a);

neposkrunenь 'neokaljan': o(t)če b(lagoslov)lû te êko pro sino tvoi edinoče-

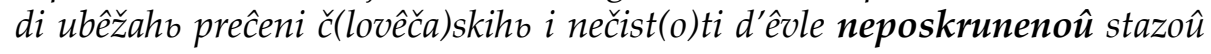
preidohs (II 13d).

Po privremenosti svojstva blizak im je oblik neodêvenb: $i$ vidê on'dê č(lovê) ka neodêvena rizami brač'nimi (I 226c). ${ }^{31}$

\footnotetext{
${ }^{26}$ Pogreška u prijevodu ili prijepisu; usp. latinski: accessit confessa, ut rediret professa, i $\mathrm{BrN}_{2}$ (449b): isp(o)v(ê)dana.

27 Usp. u BrVO (439c): êkože vidê êko otsêče se ot gori kamen bez' ruku.

28 Prijevod je pogrešan; usp. latinski tekst: quoniam Judas talia ministrantam, reprobatum potius quam honoratum videmus. Međutim, to nema posljedice na problem koji se ovdje istražuje.

${ }^{29}$ Usp. $\mathrm{BrN}_{2}$ (412c): neistaĉana.

${ }^{30}$ Uostalom, već je napomenuto da je razlog tomu drugi.

31 Iako se oblik može činiti kao sekundarni predikat, na zaključak da je riječ o atributu koji modificira objekt navodi činjenica da imenica u objektu ima vrlo opće,
} 
Sandra Požar: Stupanj popridjevljenosti participa i njegov odraz u leksikografiji... FILOLOGIJA 69(2017), 61-82

Ostali oblici u atributnoj službi čine zaseban, viši podstupanj popridjevljenih participa.

netežans 'neobrađen': i grehovb trniems okročens nečis'totoû leki niva netežana (II 71a);

neukrêplens 'neučvršćen': podana sutb oĉe $i$ v' staromb zakonê lûdemb nenaučenims i neukreplenimb ni razum'nims (I 102b; Origenova homilija na Matejevo evanđelje 5,43). ${ }^{32}$

Njima se može pridružiti oblik $\left({ }^{*}\right)$ neskrušenb 'nenarušen': dnev'ni činb noĉ'no razbiê prišastviể3 tak'mo neskrušenb čino pos'ta (I 103d), pod pretpostavkom da niječna čestica nije neopravdano, tj. pogrešno prefigirana (usp. latinski: licet diei ordo noctis interrumperetur adventu, non tamen interruptus est ordo jejunii).

\subsubsection{Treći stupanj: pridjevi}

Kako preobrazba nije uobičajen način postanka riječi u hrvatskom crkvenoslavenskom jeziku, pravih je pridjeva svega nekoliko. Bolje potvrđeni oblici pripadaju ovoj skupini zahvaljujući specijalizaciji jednoga značenjskoga segmenta ili stalnomu svojstvu, dok su oblici s jednom potvrdom doživjeli značenjsku promjenu: dva od njih znače pasivnu (ne)mogućnost (nerasmotrenı i neskrušenı), iako je potvrda prvoga problematična zbog prijevodne pogreške; dva imaju posebna značenja (nemnênь i nesolenb), iako treba napomenuti da je potonji izvorno, prije značenjskoga pomaka, također značio pasivnu nemogućnost; jedan je endocentrična složenica (nerukotvorenv; usp. Bloomfield 1963:235; Sudec 2010:193), pa je ovdje samo riječ o prefiksalnoj tvorbi; jedan je popridjevljen zahvaljujući značenju stalnoga svojstva, odnosno značenjskoga pomaka (neučenb). Oblici s jednom potvrdom, s iznimkom potonjega, jedini su pravi pridjevi, dok su oblici s više potvrda popridjevljeni u visokom stupnju, ali je njihova veza s glagolom još uvijek tvorbena. Zbog toga se u najvišem, trećem stupnju može govoriti o dva podstupnja, što se, ipak, ne odražava na leksikografsku obradu oblika u objema podskupinama kao pridjeva.

nemnên 'neočekivan': egože sretenie nem'neno nemalo vloži emu neugod'no stîj(e)nie (II 152c), lat. inopinatus;

nerukotvorenb 'nestvoren ljudskom rukom': $h(\text { rbst })_{b}$ prišadb ar'hierei

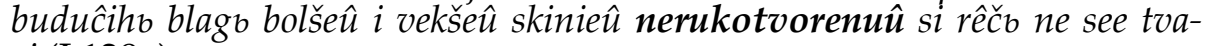
ri (I 129a);

ispražnjeno značenje ('netko'), dakle smisao je »vidje nekoga tko ne bijaše odjeven u svadbeno ruho«, a ne »vidje čovjeka kako je neodjeven«.

32 Taj bi se, budući da prevodi latinski pridjev infirmus, možda mogao smatrati i pravim pridjevom.

33 Pogrešno umjesto prišastvie; usp. BrVO 156a. 
Sandra Požar: Stupanj popridjevljenosti participa i njegov odraz u leksikografiji...

FILOLOGIJA 69(2017), 61-82

nerasmotrenb 'neshvatljiv': mati bo e(stb) vistinu êže čedoma drzo bez' meru eteru častb bez'mer'nu i nerasmotrenu vistinu nez'nanu mira hoteniê e(stb) (I 112b; homilija sv. Ambrozija biskupa na Matejevo evanđelje 20,2027); ${ }^{34}$

neskrušeno 'neuništiv': anastasii (...) neskrušenimb ven'cemb ven'čan' (II 15b); lat. immarcesibili bravio coronatus;

nesolens 'neizlječiv': stvoru plačb leki zmievo i êk(o) strkovb êk(o) nesolena e(stb) rana ego (I 260a-b, Mihej 1,8-9; lat. Quia desperata est plaga eius; hrv. Jer njenoj rani nema lijeka (Biblija 1980:908); ${ }^{35}$

neučeno 'neuk': êko ubo vistinu pros'tie lûbo neučenie vêri obakb nelažnie tor'dostan'niems i krêp'kie edinako vzvêstuûtı (I 43d).

Ovamo se može pridružiti i pridjev neiskušenb 'zao, nepošten' iz potvrde ideže i d(u)ho zlobivi neiskušeni sêbe obrelı bi (I 104c), koji je oblikom podudaran participu, ali nije izravno povezan uz glagol, nego je nastao zahvaljujući posebnosti (staro)crkvenoslavenskoga kao jezika koji je nastao u postupku prijevoda. Naime, taj oblik odgovara latinskomu pridjevu improbus 'zao, nepošten' i mehanički ga kalkira, prevodeći ga sastavnicu po sastavnicu (in- + probare 'ispitivati') i zanemarujući značenje leksema kao cjeline. ${ }^{36}$

Većina oblika s više potvrda može se smatrati pravim pridjevima jer su leksikalizirani. Naime, te potvrde imaju fiksirano, uglavnom specijalizirano značenje ili upotrebu (odnose se na istoga referenta). Tako se oblik nevrêždens ‘neokaljan' može smatrati pridjevom kada se odnosi na Bogorodicu ili koju sveticu - tada je specijaliziran u značenjskom segmentu tjelesne čistoće (djevičanstva): tako i d(ê) va m(a)riê rodi g(ospod)a na nevrêždena prebi (I 25b); po porodê d(ê)vô̂ nevreždena prebila esi (II 21d); $i$ devô̂u b(og)b $i$

\footnotetext{
${ }^{34}$ Iako nema odgovarajuće latinske usporednice, jer je prijevod pokvaren, može se zaključiti da je riječ o značenju pasivne mogućnosti, slično kao u pridjevu bezmêranb koji ovomu prethodi u navedenoj potvrdi. Latinski tekst glasi: Mater est utique, cui pro filiorum honore sollicitae immoderatior quidem, sed tamen ignoscenda mensura votorum est, a oblik ignoscenda 'ono što treba oprostiti' u prijevodu je mogao biti pobrkan s oblikom poput ignarus 'nevješt, neupućen'. Slobodan prijevod na hrvatski glasio bi: »Majci svakako treba oprostiti što se, u brizi za svoje sinove, osmjelila na taj način tražiti za njih posebnu čast.« Prijevod je pokvaren i u BrVO (172d): mati bo est' vistinu êže čedoma eteru čast' drbzo bezmêrnu nerasmotrenu vistinu neznana mira hotêniê estb.

35 Ovo je jedina potvrda prijevoda latinskoga desperatus tim leksemom u latinskocrkvenoslavenskom indeksu Kartoteke RCJHR.

36 Usp. termin pomorfemnyj perevod V. S. Jefimove za slučajeve u starocrkvenoslavenskom (Jefimova 2007:118). Takvi su slučajevi poznati i drugdje u hrvatskom crkvenoslavenskom; usp. npr. pridjev bezdarbno 'slobodan, izuzet' kao mehanički prijevod sastavnica latinskoga pridjeva immunis (RCJHR 2000:126).
} 
Sandra Požar: Stupanj popridjevljenosti participa i njegov odraz u leksikografiji... FILOLOGIJA 69(2017), 61-82

č(lovê) kb porodila esi i devô̂ nevreždena esi prebila (II 22d); egože egda vzlûblûu čista es(a)mь i egože kos'nu i nevreždena esamb (II 12d; lat. munda sum).

Slično vrijedi za nekosnens 'netaknut', čest oblik s istim značenjem prepoznatljivim izvan konteksta. Kao i oblik nevrêždenı, u specijaliziranom značenju tjelesne čistoće može se smatrati pridjevom. Na poznatost pojma izrečena sintagmom upućuje i to što se $u$ atributnoj službi pojavljuje $u$ dugom obliku. Pojavljuje se u svim trima službama. U većini je potvrda zadržano preteritno značenje, ali u nekima je glagolski dio predikata $\mathrm{u}$ futuru, pa se može govoriti o glagolskom pridjevu; čto e(stb) vrata $v$ domu g(ospod)ni zatvorena tak'mo da m(a)riê v v(ê)ki budetb nekosn(e)na (I 47a); kaê sutb vrata zatvorena $v$ domu g(ospod)ni tak'mo da mariê d(ê) va budets vsagda nekos'nena (II 31d) ${ }^{37}$; nekosn(e)na neznaema muža sl(o)vomь poče s(i)nь b(o)ži (I 52b); nez'naema nekos'nena muža sl(o)voms poče s(i)nь (I 33b); nekosnena i neznaema muža (I 68a); porodiši ubo s(i)no d(ê)vstva ne vrêdeĉi $i$ budeši obrêmenena i budeši us(a)gda mati nekosnena (I 6c); pisano e(stb) mati ego mati neposkrunena mati cêla mati nekosnena mati ego (I 24d); reče bo pisanie mati ego mati nekosnena mati cêla mati čista (I 25c); $n(a) m b d(a) n b \quad n(a) m b$ roĵ(e)nb iz' nekos'nenie d(ê)vi (I 199c); iže bo duhom' s(ve)timb ot nekosnenie matere črêva cr(ê)kvê ob'novi se (I 48b).

Slični su prethodnim dvama oblici neoskvrbnens i neposkrunens, a od njih se razlikuju po tome što se $u$ korpusu rabe samo $u$ tom značenju, a ne i u značenju tjelesne ozljede.

neoskvrbnens 'neokaljan': ženi ihs bezum'ni suts $i$ čeda ihs bezakonsna prokleto sazdanie ihs êk(o) b(la)ž(e)na e(stb) neplod'na i neoskvrnena (I 236b, Sap 3,12-13; lat. Mulieres eorum insensatae sunt, et nequissimi filii eorum. Maledicta creatura eorum, quoniam felix est sterilis: incoinquinata (...)); o

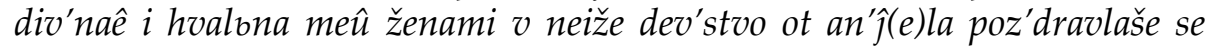
sama ob'rem'enena i neoskvrnena raz'bremenena i nestaĉena êk(o) siko e(stb)

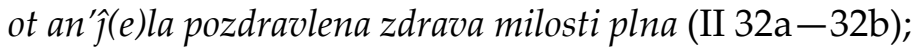

neposkrunenb 'neokaljan': budi g(ospod)i sr(bd)ce moe $i$ telo moe nepos'kruneno da ne postiždu se (II 166d); pisano e(stb) mati ego mati neposkrunena mati cêla mati nekosnena mati ego (I 24d); čaĉenimb bližnimb dnemo im'že neposkrunenoe dev'stvo i č (lovêča)sk(a)go roda sp(a)settể efifanie nams milêiši daets prebiva razumeti (I 61d).

\footnotetext{
37 Treba spomenuti mogućnost da se oblik nekos'nena u ovoj potvrdi tumači kao atribut imenici dêva u nedodirnom položaju. Rečenični naglasak na imenici dêva, koji bi pomogao pri utvrđivanju da je riječ o atributu, zbog naravi korpusa nije moguće utvrditi. Ipak, čini se da se mogućnost atributnoga tumačenja može odbaciti zbog pojmovnoga paralelizma sintagme Mariê dêva i imenice vrata.

38 Pogrešno umjesto spasitela.
} 
Sandra Požar: Stupanj popridjevljenosti participa i njegov odraz u leksikografiji... FILOLOGIJA 69(2017), 61-82

Oblik neobrêzans 'neobrezan' pridjevom čini specijalizirano značenje povezano uz vjerski obred. Upotrijebljen je i pri elipsi imenice; $i$ pov(e)lê sazidati oltare $i$ cr(ê)kve $i$ idole (...) i ostavi[ti] s(i)ni svoe neobraz(a)ni (!) i poskvrniti d(u)še ihb (I 249c; Prva knjiga o Makabejcima 1,48); ${ }^{39}$ da ne v'zveselet' se deĉeri filisteiskie ni vzraduût' se deĉeri neobrezanihb (I 209c).

Oblik neroždenv 'nerođen (o Bogu)' pojavljuje se samo u atributnoj službi, a značenjem odnosno upotrebom specijaliziran je za Boga: hvala budi $o(t)$ cu neroĵenomu sl(a)va edinočedomu s(i)nu sila vêlikomu paraklitu (II 111b); hv(a)la budi o(t)cu neroždenomu slava edinomu s(i)nu sila vêliê par(a)kl(i)tu (II 114a); soršen' resni o(ta)cb neroždenb suršen' res'ni s(i)no edinočedo soršenb res'ni $d(u) h b$ s(ve)ti vistupaûĉb (II 1c).

Ostali višekratno potvrđeni oblici popridjevljeni su na temelju značenja stalnoga svojstva, koje implicira značenjski pomak. Oblik neznans 'nepoznat' pojavljuje se u svim trima službama: $t(a) k o$ da v'sim' nez'nano bilo bi mes'to (I 252c); r (e)če da nez'nano budeto mesto don'deže budeto (I 253a); ona êže oh(rbst)b ̌̌ (lovê)k(o)mb nez'nana (I 227a); prêžde poče misliû neže têlomb ot višnago svêstovaniê nez'nanago neobičainihb slovesb da ne ustrašila se bi (I 30a); glubokihb s(love)sb i nez'nana êzika ihbže ne v'zmožeši slišati (I 255a); a u atributnoj službi i pri elipsi imenice: êko lastaci i resnotiv'ni êk(o) nez'nani $i$ poznani êk(o) umiraemi i se živi esamb (I 103c); zb radosto ot stranbnihs $i$ nez'nanihb za prav'du i svet'stvo (I 106a); eteru časts bez'mer'nu i nerasmotrenu vistinu nez'nanu mira (I 112b). ${ }^{40}$

Oblik nenaučens 'neuk' potvrđen je samo u atributnoj službi: podana sutb oĉe i v' staroms zakonê lûdems nenaučenimb i neukreplenims ni razum'nims (I 102b); sveripe i nenaučene eziki leki ribi kade naravomb s(ve)tie veri povinu (II 156c), a rabi se i pri imeničkoj elipsi: iv(a)nv (...) sa iz'veĉeniem' pokaêniê leki nenaučeni da prosikalb bi pole naplneniems (II 71a); i ottudu nenaučenihb prog'na (I 125a).

Oblik nečtovanı, iako se njegova popridjevljenost temelji na stalnu svojstvu, zanimljiv je po tome što se ne pojavljuje $u$ atributnoj službi: $v^{\prime}$ ag(a)ncê zaklans i vo d(a)vidê progonens i v' pror(o)cêh' neč'tovanb (I 140d); ibo samogo skazuets ženiha pohulena i neč'tovana i otvržena (I 144b).

Iskakanje iz ovoga stupnja pokazuje već spomenuti oblik neokroens 'neobrezan' u potvrdi da priišal' bi skvozê te neokroenb i nečists (I 28a; Izaija 52,1; prema latinskom incircumcisus et immundus). Tomu je obliku svojstveno specijalizirano značenje i upotrijebljen je pri elipsi imenice, zbog čega bi

\footnotetext{
${ }^{39}$ Potvrda je problematična jer u izvorniku stoji neobrazni. Međutim, da je riječ o tom obliku, potvrđuju inačice iz drugih brevijara u Kartoteci RCJHR.

40 Pogreška; v. gore, pod nerasmotrenı.
} 
Sandra Požar: Stupanj popridjevljenosti participa i njegov odraz u leksikografiji... FILOLOGIJA 69(2017), 61-82

se očekivalo da je razumljiv. Ono što ga čini posebnim jest i to što je kratak jer upućuje na neodređena referenta (usp. hrvatski prijevod Ivana Šarića: »jer ni jedan, koji je neobrezan i nečist, ne će više ući u tebe«; Sveto pismo 1942:396). S druge strane, nije institucionaliziran (nema drugih potvrda u korpusu Kartoteke RCJHR) i položaj mu nije jednak pridjevu neobrêzanı.

Kako bi obrada korpusa bila potpuna, treba se osvrnuti i na oblik nestroenihb u potvrdi podadem' se leki slugi b(o)ž(i)e $v$ trpeni mnozê $v$ trpeni mnozê (!) v skrbêh v bêdahs $v$ tugahs v ranahs v tam'nicahs v trudehs nestroenihb (I 103c), koji je u bazi označen kao particip, ali očito pogrešno. Oblik ne postoji u Kartoteci RCJHR (ni pod glagolom stroiti), a isto mjesto iz Druge poslanice Korinćanima $(6,5)$ u BrVO (155b) glasi: v nestroenii v trudêh (lat. in seditionibus, in laboribus), dakle s imenicom nestroenie 'buna'. Stoga i ovu potvrdu valja interpretirati stezanjem dvaju $i i$, što ni inače nije neobično kod imenica sa završetkom -ie, slično kao što nije neobično ni nebilježenje završnoga /j/, usp. primjerice genitiv množine nestroeni. Konačno, inačice istoga mjesta u drugim brevijarima imaju isti oblik: nestroeni (BrVat 5 75b), nes'troeni $\left(\right.$ BrN $\left._{2} 73 \mathrm{~d}\right)$.

\section{Pitanje leksikografske obrade}

Prikazana raščlamba pokazala je da svaku potvrdu treba promatrati zasebno, pa će katkad isti oblik moći biti i particip i pridjev, te stoga u rječničkoj obradi naveden kao potvrda dotičnoga glagola i kao zasebna natuknica. Pitanje je, međutim, kako u leksikografskoj obradi postupiti s popridjevljenim participima, što se najviše odnosi na oblike u službi sekundarnoga predikata kojima se značenje nije promijenilo u odnosu na osnovni glagol. Iz perspektive suvremenih jezika za takve oblike nije potrebno uvođenje zasebne natuknice, čak ni s gramatičkom oznakom koja kazuje da je riječ o popridjevljenom participu. U rječniku kojemu je cilj samo objašnjenje značenja leksema (kao što je radna inačica rječnika Drugoga beramskoga brevijara) bilo bi dobro leksikografsku obradu svesti na najmanju mjeru, tj. na slučajeve kod kojih je utvrđena značenjska promjena. S druge strane, povijesni rječnici kao što je $R C J H R$, koji se temelje na tekstovnim potvrdama, bilježe takve oblike kao zasebne natuknice. U tom slučaju dobrodošla je gramatička odrednica (za zasebnu kategoriju) »adj. ptc.« koja je, za razliku od Slovníka jazyka staroslověnského na koji se RCJHR oslanja, uvedena pri pripremnoj obradi korpusa u Kartoteci $R C J H R .^{41}$

Isti odgovor vrijedi i za drugo pitanje koje se postavlja o ovdje istraživanim oblicima, a to je treba li popridjevljene participe s negacijskim

${ }^{41}$ Usp. o tome i Kovačević 2016:86. 
prefiksom obrađivati zasebno zbog prefiksa. Iako prefiksi u pravilu imaju "punije" značenje nego sufiksi, činjenica da je negacija univerzalna kategorija (usp. Kovačević 2016) i da nema kategorijalnih ograničenja u prefigiranju negacijskim prefiksom omogućuje, opet iz suvremene perspektive, da se taj prefiks zanemari u leksikografskom opisu. Primjerice, u rječnicima suvremenih živih jezika bilo bi nepotrebno umnažanje natuknica kada bi se u njih unijele sve riječi koje se mogu zanijekati. Međutim, u povijesne rječnike leksemi prefigirani negacijskim prefiksom iz gornjega se razloga ipak unose kao natuknice, tim više što bi unošenje potvrde kao pojavnice glagola koji ne bi imao negacijski prefiks vjerojatno bilo još manje prihvatljivo.

\section{Zaključak}

Kako bi se utvrdio stupanj popridjevljenosti oblika zanijekanih pasivnih preteritnih participa potvrđenih u tekstu Drugoga beramskoga brevijara, ispitani su značenjski i sintaktički čimbenici. Najvažnije je pitanje u vezi sa značenjem postoji li značenjski pomak ili promjena; ako da, riječ je pridjevu. Najčešće je značenje pasivne mogućnosti (npr. nerasmotrenz), a uz to se pojavljuju neka posebna značenja (npr. nemnênb). Značenjska je promjena ključan kriterij popridjevljenosti uz koji se, ako je zadovoljen, svi ostali mogu zanemariti. Ako značenjska promjena i nije utvrđena, oblik može biti popridjevljen ako mu značenje nije uvjetovano kontekstom, nego je jasno i kada je oblik samostalan, i to zahvaljujući značenjskoj specijaliziranosti. Ta je pojava na djelu pri značenjskoj specijalizaciji pridjeva nevrêždenı i nekosnen $\mathrm{u}$ u potvrdama koje se odnose na djevičanstvo, pridjeva nerožden koji se odnosi na Boga, te pridjeva neobrêzanı koji je povezan s vjerskim obredom.

Raščlamba je pokazala da svaku potvrdu pojedinoga oblika treba promatrati zasebno, pa će oblici kao takvi biti homonimni (ali ne u leksikografskom smislu, jer će samo jedan dio para biti natuknica). Utvrđena su tri stupnja: neki su oblici posve popridjevljeni, neki pripadaju glagolskim oblicima, a većina ih je u srednjem stupnju popridjevljenih participa. Stupnjevi se ugrubo preklapaju sa sintaktičkim službama, osobito kad je riječ o sekundarnom predikatu, gdje oblici u pravilu, osim leksikaliziranih, izražavaju privremeno svojstvo. Oblici u predikatu mogu biti glagolski i imenski. Prvi su posebni po tome što morfološki, negacijskim prefiksom, izražavaju sintaktičku, i to rečeničnu negaciju. Ti oblici zbog tvorbene specifičnosti zaslužuju leksikografsku obradu iako su po naravi glagolski (izriču pasiv). Oblici koji su dio imenskoga predikata smatraju se njegovim imen- 
Sandra Požar: Stupanj popridjevljenosti participa i njegov odraz u leksikografiji... FILOLOGIJA 69(2017), 61-82

skim dijelom kada to daje naslutiti njihovo značenje, koje je specijalizirano ili prepoznatljivo izvan konteksta te se zbog toga može reći da su leksikalizirani, iako se mogu preoblikovati u neki drug tip pasivne konstrukcije. Leksikografska obrada oblika koji ostaju u međustupnju između participa i pridjeva ovisi o načelima i koncepciji pojedinoga rječnika.

\section{Izvori}

Digitalna baza Beram (beram.stin.hr)

Drugi beramski brevijar, I. dio (Badurina Stipčević, Vesna; Botica, Ivan; Dimitrova, Margaret; Dürrigl, Marija-Ana; Hristova Šomova, Iskra; Kovačević, Ana; Kuhar, Kristijan; Mihaljević, Milan; Mokrović, Ljiljana; Požar, Sandra; Radošević, Andrea; Šimić, Marinka; Vela, Jozo; Vince, Jasna; Vučković, Josip; Zubčić, Sanja; Žagar, Mateo. Preslovljeni Temporal Drugoga beramskog (ljubljanskog) brevijara, 2015.; https://beram.stin.hr/hr/ transliteration/53)

Drugi beramski brevijar, II. dio (https://beram.stin.hr/hr/transliteration/803/1)

Kartoteka Rječnika crkvenoslavenskoga jezika hrvatske redakcije (Staroslavenski institut)

Latinsko-hrvatskocrkvenoslavenski indeks iz Kartoteke RCJHR (Staroslavenski institut)

Digitalizirana kartoteka RCJHR (rjecnik.stin.hr)

Kratice imena spomenika iz Kartoteke Rječnika crkvenoslavenskoga jezika hrvatske redakcije $e^{42}$

$\mathrm{BrN}_{2}$ - Drugi novljanski brevijar

BrVat $_{5}$ - Vatikanski misal Illirico 5

BrVat $_{6}$ - Vatikanski misal Illirico 6

BrVO - Brevijar Vida Omišljanina

MNov - Misal kneza Novaka

\footnotetext{
42 Podatke o spomenicima v. u RCJHR 2000:XXXI-XXXVI.
} 
Sandra Požar: Stupanj popridjevljenosti participa i njegov odraz u leksikografiji... FILOLOGIJA 69(2017), 61-82

\section{Citirana literatura}

Babić, Stjepan. 2002. Tvorba riječi u hrvatskome književnome jeziku. Nacrt za gramatiku. Treće, poboljšano izdanje. Zagreb: HAZU - Globus.

Baker, Mark C. 2003. Lexical Categories: Verbs, Nouns and Adjectives. [Cambridge Studies in Linguistics, 102.] Cambridge: Cambridge University Press.

Bauer, Laurie. 2002. English word formation. Ninth edition. Cambridge: University Press.

Bauer, Laurie. 2003. Introducing Linguistic Morphology. Second edition. Washington: Georgetown University Press.

Belaj, Branimir. 2002. Kategorija gotovosti i vremenska vrijednost pasivnoga predikata. Jezikoslovlje 3/1-2,1-16.

Belić, Aleksandar. 1958. O jezičkoj prirodi i jezičkom razvitku I. Beograd: Nolit.

Biblija: Stari i Novi zavjet. 1980. Glavni urednici: J. Kaštelan, B. Duda. Zagreb: Kršćanska sadašnjost.

Bloomfield, L. 1963. Language. [Prvo izdanje 1933.] Chicago \& London: The University of Chicago Press.

Brinton, Laurel J. - Elizabeth Closs Traugott. 2005. Lexicalization and Language Change. Cambridge: Cambridge University Press.

Dukat, Zdeslav. 1990. Gramatika grčkoga jezika. Zagreb: Školska knjiga.

Đorđić, Petar. 1930. Trpni glagolski pridev prošlog vremena u staroslovenskom jeziku, grčkom i latinskom tekstu. Južnoslovenski filolog 9, 273278.

Đorđić, Petar. 1931. O staroslovenskim trpnim pridevima. Južnoslovenskifi$\operatorname{lolog} 11,89-173$.

Embick, David. 2004. On the Structure of Resultative Participles in English. Linguistic Inquiry 35/3, 355-392.

Gaeta, Livio. 2013. Affix ordering and conversion: looking for the place of zero. Lingue e linguaggio 12/2, 145-170.

Gortan, Veljko - Oton Gorski - Pavao Pauš. 1966. Latinska gramatika. Treće izdanje. Zagreb: Školska knjiga.

Haspelmath, Martin. 1994. Passive Participles across Languages. Voice: form and function. Edited by B. Fox, P. J. Hopper. [Typological studies in language, vol. 27.] Amsterdam: John Benjamins, 151-177.

Jefimova, Valerija Sergejevna. 2007. O staroslavjanskom kal'kirovanii kak specifičeskom sposobe slovoobrazovanija. Byzantinoslavica 65, 117128.

Knežević, Božana - Irena Brdar. 2010. On the nature of Adjectival Resultatives - Corpus-based Evidence. Suvremena lingvistika 70, 209-228.

Kovačević, Ana. 2016. Negacija od čestice do teksta: Usporedna i povijesna ra- 
Sandra Požar: Stupanj popridjevljenosti participa i njegov odraz u leksikografiji... FILOLOGIJA 69(2017), 61-82

ščlamba negacije u hrvatskoglagoljskoj pismenosti. [Bibliotheca Glagolitica Croatica 3.] Zagreb: Staroslavenski institut.

Levin, Beth - Malka Rappaport. 1986. The Formation of Adjectival Passives. Linguistic Inquiry 17, 623-661.

Marković, Ivan. 2009. Rezultativni sekundarni predikat u hrvatskome. Suvremena lingvistika 68, 221-246.

Marković, Ivan. 2012. Uvod u jezičnu morfologiju. Zagreb: Disput.

Matthews, Peter H. 1991. Morphology. Second edition. Cambridge: Cambridge University Press.

Požar, Sandra. 2014. Pridjevi. Hrvatski crkvenoslavenski jezik. Priredio M. Mihaljević. Zagreb: Hrvatska sveučilišna naklada i Staroslavenski institut, $151-188$.

RCJHR: Rječnik crkvenoslavenskoga jezika hrvatske redakcije. Zagreb: Staroslavenski institut, 1991.-

RCJHR. 2000. Rječnik crkvenoslavenskoga jezika hrvatske redakcije I. 2000. Glavni urednici: B. Grabar, Z. Hauptová, F. V. Mareš. Zagreb: Staroslavenski institut.

RCJHR. 2015. Rječnik crkvenoslavenskoga jezika hrvatske redakcije II. 2015. Glavne urednice: Z. Hauptová, Z. Ribarova. Zagreb: Staroslavenski institut.

Silić, Josip - Ivo Pranjković. 2005. Gramatika hrvatskoga jezika: za gimnazije i visoka učilišta. Zagreb: Školska knjiga.

Sleeman, Petra. 2011. Verbal and adjectival participles: internal structure and position. Lingua 121.10, 1569-1587.

Sleeman, Petra. 2014. From Participle to Adjective in Germanic and Romance. Adjectives in Germanic and Romance. Edited by P. Sleeman, F. Van de Velde and H. Perridon. [Linguistik Aktuell / Linguistics Today 212.] Amsterdam: John Benjamins, 171-198.

Sleeman, Petra - Dana Niculescu. 2015. Adjectivization of participles in Romance: A gradual process? Romance Linguistics 2012: Selected papers from the $42^{\text {nd }}$ Linguistic Symposium on Romance Languages (LSRL), Cedar City, Utah, 20-22 April 2012. Edited by J. Smith and T. Ihsane. [Romance Languages and Linguistic Theory 7.] Amsterdam: John Benjamins, 245-260.

Slovník jazyka staroslověnského I - IV. 1959. - 1997. Hlavní redaktor J. Kurz. Praha: Academia, Nakladatelství Československé akademie věd.

Sudec, Sandra. 2010. Tvorba pridjeva u hrvatskome crkvenoslavenskome jeziku. Neobjavljena doktorska disertacija. Sveučilište u Zagrebu.

Sudec, Sandra. 2012. Upotreba kratkih i dugih pridjevskih oblika u hrvatskom crkvenoslavenskom jeziku. Peti hrvatski slavistički kongres: Zbornik 
Sandra Požar: Stupanj popridjevljenosti participa i njegov odraz u leksikografiji...

FILOLOGIJA 69(2017), 61-82

radova s Međunarodnoga znanstvenog skupa održanoga u Rijeci od 7. do 10. rujna 2010. Uredile M. Turk i I. Srdoč-Konestra. Rijeka: Filozofski fakultet Sveučilišta u Rijeci, 61-68.

Sveto pismo Staroga i Novoga zavjeta, svezak II. Stari zavjet: Poučne i Proročke knjige. 1942. Preveo i bilješke priredio Ivan Ev. Sarić. Sarajevo: Akademija Regina Apostolorum.

Večerka, Radoslav. 1993. Altkirchenslavische (altbulgarische) Syntax II. Die innere Satzstruktur. Monumenta linguae slavicae dialecti veteris, knj. 34. Freiburg i. Br.: U. W. Weiher.

\title{
Degree of participle adjectivization and its reflection in lexicography: study of the passive past participles prefixed by the prefix ne- in the corpus of the Second Beram Breviary
}

\begin{abstract}
Participles are by nature dual categories and their adjectivization poses a theoretical problem in word formation primarily because it is precisely the identical syntactic functions of adjective and passive participle that enable the adjectivization. Between the verbal participles and fully adjectivized passive participles (i.e. adjectives), there is a number of mixed forms that cannot be interpreted unambiguously. The three points on the scale between verbs and adjectives are the subject of this paper, which aims to detect the degree in which participles are adjectivized in the corpus of the Second Beram Breviary database of the Center of Scholarly Excellence for Croatian Glagolitism. The results were used to study the way in which this theoretically problematic phenomenon is reflected in lexicography, which by its nature tends to precision and unambiguity.

Ključne riječi: hrvatski crkvenoslavenski jezik, pasivni particip, pridjev, popridjevljenje, Drugi beramski brevijar, Rječnik crkvenoslavenskoga jezika hrvatske redakcije

Keywords: Croatian Church Slavonic language, passive participle, adjective, adjectivization of participles, Second Beram Breviary, Dictionary of the Church Slavonic Language of Croatian Redaction
\end{abstract}

